\title{
The Biblicism of the Korean Protestant churches: Its origin and early development
}

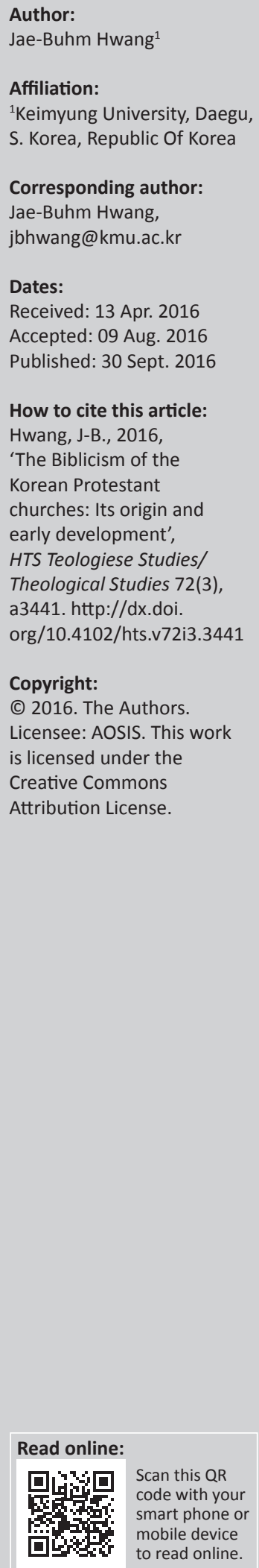

\begin{abstract}
The purpose of this article is to clarify the origin and early stages of the Biblicism of the Korean Protestant churches in general, and of the Presbyterian Church of Korea (PCK) in particular. The Biblicism is very important for Korean Protestant churches, because it is believed to be a main cause of their unusual growth on the one hand, and on the other hand, of their Fundamentalism and many schisms in the post-liberation era. The article, in the beginning part, investigates the four crucial elements of Korean Biblicism and then examines how the four elements worked together to form a resilient Biblicism whose two distinctive theological forms were practical on the one hand, and dogmatic (fundamentalist), on the other. Among the four basic Biblicist elements, the first was the firm Biblicist theology of the early North American missionaries in Korea who tried to follow and flower their original, puritanical and Old Princeton theology in Korea. The second was Korean Protestants' original, Neo-Confucian biblicism, which facilitated them to readily accept the missionaries' Biblicist teachings of the Bible. The third element was the so-called Nevius [Mission] Methods, which emphasised simplistic Biblicist Bible studies, and offered both opportunities of learning and ways to become meaningful leaders in their communities. The fourth and last element was the Biblicist creed of PCK, which became the fundamentalist weapon against its modernist or liberalist wing. To sum up, Korean Biblicism has been the result of those four Biblicist elements working together. The Korean Biblicism was developed into two more or less different positions; the one being practical, exemplified by Rev. Samuel A. Moffett; and the other, dogmatic and fundamentalist, represented by Rev. Dr W.D. Reynolds.
\end{abstract}

\section{Introduction}

This article aims at elucidating the origin and early period of the Biblicism of the Korean Protestant churches, which is believed to be a main cause of their unparalleled growth on the one hand, and on the other hand, of their Fundamentalism and many schisms in the post-liberation era. The focus, however, will be on the Biblicism of the Presbyterian Church of Korea (PCK) because, being the largest and most influential among the Korean Protestant churches, the Church has played a decisive role in forming the Biblicism of the Korean Protestant churches in general. The term Biblicism or Biblical literalism itself has various meanings, and furthermore, it has an even deeper meaning here in Korea than in the West, because it was derived from Koreans' centuries-old reverence for Buddhist and Confucian bibles. So it is true that the vast majority of Korean Protestants in general are on the side of the American evangelicals who, according to Bartkowski (1996:260), believe that 'the Bible [is] authoritative or inspired (i.e. part of which may be considered metaphorical)'. Yet perhaps more than the half of them, especially their conservative wing, are like American fundamentalists who, Bartkowski (1996:260) says, believe that 'the Bible is infallible or literally true without exception'. Thus it is to be mentioned that in this study the term Biblicism may have a combined meaning of both American evangelicals and fundamentalists.

There has been no extensive study on the origin and early development of Biblicism in Korea. Studies on Korean Biblicism have been mainly for or against Dr Hyung-Yong Park's doctrine of the verbal plenary inspiration of the Holy Scriptures. Becoming the heroic leader of the conservative wing in the Korean modernist-fundamentalist controversies, Dr Park established a dissenting Presbyterian denomination (Hapdong), eventually producing a very conservative theology based on the Biblical inerrancy doctrine. Thus almost all of the researches on Biblicism in Korea are dealing with his somewhat fundamentalist position, either rejecting or seconding it. This study may fill the gap, providing some clues to understanding not only the Biblicism as a characteristic element of Korean Christianity, but the Korean modernist-fundamentalist controversies.

This study will examine two aspects of Korean Biblicism: first its germination and early progress, and then its theological - more or less fundamentalist - formation. The first aspect, covering 
roughly from 1884 to the 1920s, deals with what the four main elements of Korean Biblicism were, and how they worked together to form a sturdy Korean Biblicism. The second aspect, approximately spanning from the 1910s to 1930s, treats how the American missionaries, as the theological leaders of PCK, came to develop two somewhat different Biblicisms: practical and dogmatic (fundamentalist).

\section{The origin and early development of the Biblicism in Korean Protestantism}

There were surely quite a lot of Biblicist elements for Korean Protestants, but we identify four distinctive elements, which are believed to have operated together to form a robust Biblicism. The first original element was definitely the solid Biblicist theology of the early North American missionaries in Korea whose Biblicist teachings were even fervently accepted by their Korean followers. The second was Korean Protestants' original biblicism, which, having been derived from Korean Neo-Confucianism, facilitated them to readily receive the missionaries' Biblicist teachings. The third, institutional element was the so-called Nevius [Mission] Methods, which emphasised simplistic Biblicist Bible studies, providing Korean converts with not only coveted literacy, but Christian learning, which also meant Western learning. This new educational system, which the Bible studies entailed, brought about an outstanding growth of Korean Protestant churches, which in turn, made them take Biblicism for granted, paving the way to fundamentalism. The fourth and last, legal element was the Biblicist creed of PCK, which was sanctioned in 1907 by its founding Presbytery or the Independent Korean Presbytery (Doknohoe). The creed, also known as the Twelve Articles of Faith, had an emphatic Biblicist article, which has even confirmed the Biblicist stance. Hence, the Korean Biblicism has been the product of those four Biblicist elements working together and it is necessary to examine what each element was, and how they worked together to form a unique Korean Biblicism with a fundamentalist outlook.

\section{The Biblicist theology of the North American missionaries in Korea}

There is no doubt that the North American missionaries in Korea who, having planted and led PCK for its formative era, played a pivotal role in forming its dominantly Biblicist theology. So it is crucial to clarify what kind of theology they had brought to Korea. It is plain that the majority of North American Presbyterians before the fundamentalist-modernist controversies in the 1920s had an old Princeton (HodgeWarfield line) theology based on Biblicism. As it is well known, one of the features of this theology was its emphasis on the plenary and verbal inspiration of the Holy Scriptures, which was taken for granted by most of the North Americans of the time. ${ }^{1}$ So J.B. Rogers and D.K. McKim (1979:369) say:
'The Presbyterian churches in the USA from 1893 to 1910 took the Hodge-Warfield line of the Biblical inerrancy as a content of confession.' Hence, the absolute majority of the North American Presbyterian missionaries in those days naturally had the Biblical inerrancy doctrine, which had an implicitly fundamentalist inclination. As a matter of fact, Dr Arthur Brown (1921), who was the general secretary of the [American] Presbyterian Board of Foreign Missions, said:

The typical [North American] missionary of the first quarter century after the opening [in 1882] of the country [Korea] was a man of the Puritan type. He kept the Sabbath as our New England forefathers did a century ago. He looked upon dancing, smoking, and card-playing as sins in which no true follower of Christ should indulge. In theology and biblical criticism he was strongly conservative, and he held as a vital truth the premillenarian view of the second coming of Christ. The higher criticism and liberal theology were deemed dangerous heresies. In most of the evangelical churches of America and Great Britain, conservatives and liberals have learned to live together in peace; but in Korea the evangelical liberal, whose interpretation of the Bible differs from the commonly accepted one, sometimes has a rough road to travel. (p. 540)

This tendency is also obvious when seen from the fact that the majority of the Korea missionaries were the American recruits of SVM (the Student Volunteer Movement for Foreign Missions), ${ }^{2}$ whose theology was largely revivalist and Biblicist. They seemed to stress Bible study even more in Korea than anywhere else, as Dr Dae Young Ryu (2008) states:

\begin{abstract}
More important, the SVM's influence was seen in American missionaries' heavy dependence on revivalistic methods of personal conversion and especially their emphasis on Bible study, individual pietism, and evangelism. From the beginnings, the scriptures occupied a prominent place in Korea missions, perhaps unparalleled by any other mission field in the world ... The scriptures were, in fact, the single most important contributor to the birth and growth of the Korean church. No wonder, then, that missionaries characterised Korean Christianity as a 'Bible Christianity' and the Korean Christian as a 'Bibleloving Christian'. (p. 392)
\end{abstract}

So it is clear that the Korea missionaries from North America by the turn of the 20th century had a sturdy Biblicism, although it was not articulated as a doctrinal fundamentalism up until the 1920s. As we will see later, Rev. Samuel Moffett, who was a pioneering and leading American Presbyterian (North) missionary in Korea, had a healthy Biblicist theology, which did not have a fundamentalist tendency. The Biblicist theology of Rev. William Reynolds, who was a successor to Rev. Moffett, was almost the same as Moffett's up to 1930 , but after that, turned out to be fundamentalist gradually.

\section{Early Korean Christians' traditional Neo-Confucian Biblicism}

When the Korea missionaries from North America taught the Bible in a Biblicist way to their Korean followers, the latter missionaries to Korea during the period of 1905-1909, 81 were SVM volunteers'. 
wholeheartedly accepted the Biblicist teachings of the missionaries, together making their Biblicist Bible study classes a hallmark of the early Korean Protestant churches. Here one can assume that there was a hermeneutic catalyst that caused Korean Protestants to embrace the Biblicist teachings of the missionaries. The catalyst was Koreans' original Confucian biblicism, which stemmed from Korea's centuries-old NeoConfucianism. So the triumph of Biblicism in the Korean Protestant churches was a synergy effect of the Biblicist teaching of the North American missionaries and their Korean followers' acceptance of it in a Neo-Confucian biblicist way.

The Korean Neo-Confucian Biblicism, together with reverence for the classical works and bibles, originated from the Korean traditional Neo-Confucian educational system, which was prevalent throughout the Chosun Korea (the 15th-19th centuries), until it was replaced by the modern educational system in the early part of the twentieth century. The NeoConfucian education aimed at producing the literati who became the ruling class. In a Neo-Confucian culture, therefore, literature, education and literati were the most valued, and this was even more the case in Korea, where Neo-Confucianism was predominant for five centuries. So observed Rev. J.S. Gale (Jan., 1914), a Canadian missionary in Korea:

Literature has been everything to Korea. The literate was the only man privileged to ride the dragon up into the highest heaven. The scholar could not only look at the king but could talk with him. The pen was master of the sword. Could you but read or intone or expound the classics, you materially may be dropping to tatters, but still the world would wait on you, listen, regard fully and show honor. ... Korea is not commercial, not military, not industrial, but is a devotee of letters. She exalts books, and so the Book of all books [the Bible] finds its pathway prepared, and as by a kind of prophetic prescience, a welcome accorded which is perhaps greater than that seen in any other part of the world. (p. 5f.)

The Neo-Confucian education emphasised studies and memorisation of the classical Confucian bibles and works, taking the biblicist interpretation of them for granted. The education was done largely by Gang, in which the boy students first learned about the Chinese characters and sentences from Confucian bibles, and then rhythmically recited them aloud, trying to memorise them (Choi 2008:346). The Chinese sentences, which were from Chinese Confucian bibles like Dongmongseonseup, Myeongsimbogam and Sohag, were largely teaching about filial piety, loyalty, courteousness and Confucian ethics and cosmology. The students usually metrically recited aloud some pre-ordered sentences 100 times, kneeling down toward a wall (Choi 2008:346f.). In the process, the students possibly did not, and could not, straightforwardly understand the millennia-old Chinese words and sentences, but they tried to memorise them, assuming that the words and sentences were literally and historically true. Furthermore, in the Neo-Confucian educational system, the literati in general, and the teachers in particular, were regarded like fathers and kings, making their biblicist interpretation and teaching something unquestionable. So it is plain that this Neo-Confucian biblicist educational system itself entailed a resilient biblicism.
It is remarkable that the Neo-Confucian biblicism involved a unique hermeneutic, which may be called 'contemporaneous hermeneutics' in which modern readers read the Confucian classics, as if Confucius, who lived in the fifth century B. C., was telling the words in the classics in front of them. Yi, Toegye, the most important Neo-Confucian authority in Korea, said (Kalton 1988:194):

[A]s day breaks, rise, brush your teeth, comb your hair, and don your robes and cap. Then, sitting erect, compose your body and recollect your mind, making it as luminous as the rising sun; become solemn and silent, ordered and even, empty and lucid, still and undivided. Then open your books and enter the presence of the sages and wise men; Confucius is seated, Yen Hui and Tseng Tzu attend before and behind. Personally and reverently attend to the words of the sage Master; carefully going over and reconsidering the questions and discussions of the disciples, settle them [in your own mind]. ${ }^{3}$ (p. 194)

So Confucian students had such a contemporaneous hermeneutic by which they seemed to study under the direct tutorages of the great sages, even transcending more than two millennia. This hermeneutic, however, was possible only when they believed that their bibles contained the real words of the sages, this belief entailing a reverential biblicism. As a matter of fact, this kind of a contemporaneous hermeneutic was a matter of everyday life for pre-modern, Neo-Confucian Koreans. So observed Rev. Dr James S. Gale (1898), one of the leading missionary leaders in Korea:

He [a Korean] compares the minor details of life about him with what went on in the days of [ancient Chinese] king Sun - a contemporary of Noah - with as much assurance as we would talk of the events of yesterday. (p. 189)

It is plain, then, that such a contemporaneous hermeneutic of pre-modern Koreans, which had been sustained through serious studies of two millennia-old classics, effectively caused Korean Christians to accept the Biblical accounts as historical facts. So noted Dr Gale (Jan., 1914):

When Western worlds are illimitable distances removed from the kind of life found in the Scriptures, Korea sees herself one with the Bible in the common walks and ways of men and so prepared to appreciate the times of Abraham, Isaac and Jacob, as well as those of Peter, James, and John. (p. 5)

Dr Arthur Brown (1921) also reported:

The accounts of the Garden of Eden, the experience of Jonah, the virgin birth of our Lord, the resurrection of Lazarus, and the gates of pearls and streets of pure gold in the Heavenly City were taken as historical descriptions of actual facts. Nowhere, in the world is there a higher percentage of church members who pray, study the Bible, attend devotional services, give proportionately of their money, and manifest evangelistic zeal in spreading the gospel. (p. 546)

Rev. Dr Gale (Apr., 1914) took good advantage of this contemporaneous hermeneutic, and advised his Korean

3.Also refer to what Zhu Xi (1983:44), the originator of Neo-Confucianism, said in the 12th century: 'Students must read those passages in the Analects in which the disciples [of Confucius] ask questions as if it were the students themselves who were asking the questions. Similarly, they should treat Confucius' replies as if they were being heard right now. Then, as a matter of course, students will come to grasp were being heard right now. Then, as a matter of course, students will come to grasp
things. Even if Confucius or Mencius were to be born again, that which they would teach people would be nothing than this' Quoted from Makeham (2003:198). 
Christian followers to study the Holy Scriptures almost the same way they had studied Confucian bibles.

As for the work to be accomplished; it is first to get the contents of the Scriptures well into the memory and understanding of the student. The whole record from Genesis to Revelation is what is required to be brought into touch with the awakened faculties of the mind.... As [Korean Confucian] scholars knew the Sa-so Sam-kyong [Confucian Four Books] in the old days, so should they [Christian students] now lay hold of the Scriptures with the understanding and the memory and make it a part of their very being, till its texts, its stories, and its personages troop through the mind and mix with all the happenings of the day. (p. 115)

It seems that Rev. Kil, Sŏn-ju (1869-1935), who has been called the father of the Korean Presbyterian Church, was a perfect Korean Biblicist, being the most illustrious example for what Rev. Dr Gale said above. Having been originally a practitioner of a syncretic religion of Confucianism, Daoism and Buddhism, he had studied the bibles of those religions through a contemporaneous hermeneutic. Then, having accepted Christianity in his 28th year (1897), he intensively read the Bible in a Biblicist way, immediately regarding it as the Word of God (Kil 1980:73). He then established, and for the rest of his life carried out his own daily devotional office focusing on reading, reciting and studying the Bible: getting up early around five o'clock, praying for tens of minutes, reading and reciting the Book of Revelation for 20 minutes, studying the Bible, preparing for sermons for about three hours, and reading books for about two hours. ${ }^{4}$ For him the Bible did not become merely a daily bread, but his blood and flesh. His passionate Biblicism was a natural product of his life, which was moving around the Bible. His Biblicism was sometimes mild, accepting its metaphorical interpretations, but strict and fundamentalist some other times. His rigorous Biblicism is clearly shown in his pre-millennialist reading of the Bible. He most earnestly tried to justify that the Bible verses that speak of, or allude to, the imminent second coming of Jesus Christ are literally true, and will be realised soon (Kil 1935:14-16).

Here it is to be mentioned that Koreans' deep reverence for letters and bibles with a strong biblicism led them, especially the uneducated, to attend a local church where they could learn letters easily through Bible studies from missionaries and pastors. It is also to be acknowledged that what made easy and boosted the learning process was that the missionaries chose to use the vernacular Korean language, whereas the Neo-Confucian literati were using Chinese characters, which were much harder to learn than the former. This explains why the uneducated in general, and the underprivileged and women in particular, swarmed to the churches, making Korean Protestant churches grow spectacularly.

4.This daily time table is what the author of this article reconstructed on the basis of the two different sources: Kim, Lin-Sŏ (1936:28) and Kil, Chin-gyŏng (1980:181). As a result, Kil ended up reading 'the Old Testament 30 times, Gens, the Book a result, Kil ended up reading the Old Testament 30 times, Genesis, the Book of Esther, and Isaiah 540 times, the New Testament 100 times, and the Book of frevation 10 thousand times' (Kil 1980.181). Further 'Kil in both the more who quite frequently heard his sermons (Chun 1964:43), says: "Kil in both the morning and the evening recited part of the Book of the Revelation from memory according to Daoist or Confucian recitation rhythms'.

\section{The significance of the Nevius (Mission) methods for the Korean Biblicism}

As we have seen above, the two formative Biblicist elements of the Korean Biblicism were the Biblicism of the Korea missionaries from North America, and that of traditional Neo-Confucian Koreans. Yet if these two elements only existed, without any sociopolitical system institutionalising them, they have not been able to develop into that characteristic Biblicism, which has had an immensely significant and lasting impact on the Korean Protestant churches. It was definitely the Nevius [Mission] Methods that institutionalised the Biblicist elements, creating a nationwide Bible study system in which every new convert could develop his or her Christian identity and leadership, and which became the best educational and socio-political magnet to attract a multitude of poor and uneducated modern Koreans, who had for long been marginalised in political, educational and religious terms.

The Nevius (Mission) Methods (NM), which were adopted in 1890 by the Korea missionaries from North America, were called a 'three selfs' method: self-propagation, self-support and self-government (Kim 2001:598). The 'three selfs' were realised only through the robust Biblicist Bible study classes, which, therefore, became the cornerstone of the NM. According to Clark (1930:33-34), NM is as follows:

- missionary: personal evangelism through wide itineration

- self-propagation: every believer a teacher of someone and a learner from someone else better fitted; every individual and group seeking by the 'layering method' to extend the work

- self-government: every group under its chosen unpaid leaders; circuits under their own paid helpers who will later yield to pastors

- self-support with all chapels provided by the believers; each group as soon as it is founded beginning to pay towards the circuit helper's salary

- systematic Bible study for every believer under his group leader and circuit helper

- strict discipline enforced by Bible penalties.

It is clear that the 'three selfs' were actually sustained by 'systematic Bible study' (No. 5), which was carried out in a Biblicist way. Rev. Dr Charles Allen Clark (1930:242f.), who was one of the most important leaders of NM, stated: 'If there were no Bible study classes, the NM was not successful'. Also important was No. 6: 'strict discipline' for those who did not complete the classes. In reality, almost every Korean Protestant not only attended a regular Sunday worship service, but a Sunday morning Bible study class. Furthermore, he or she was required to attend special yearly Bible study classes, which lasted for 1-2 weeks. An American missionary, who studied how the Korean Bible study classes worked, reports (Student Volunteer Movement for Foreign Missions 1909): 
The study and the practice of the word of God play a large part in all church plans and church policies in Korea. It is the largest selling book in the Empire today, and already forms a potent force in the re-creation of the thought-life of Korea. It is found in all Christian homes and is cherished as the foundation of the family altar. It is not only read by the individual Christian, but it is studied and practiced by the great body of Christians. One of the most successful institutions we have in the church life is the Bible Institute, which is in fact a workers' training class, and a large part of the time of missionaries and native pastors is occupied in holding these training classes. They meet at central points and are attended by the workers and adult members of the churches contiguous to the central point where the class is held. The Bible is the principal text book, studied systematically, book by book, and topic by topic. Usually ten hours a day is put in on this study. These classes last from a week to three weeks. There are separate classes for men and for women. Last year, fully 50000 Korean Christians, or one in every five of the entire membership of the Church, took these courses of study. This constitutes one of the greatest Laymen's Movements to be found anywhere on earth. (p. 309)

Seeing Korean Protestants' zeal for Biblicist Bible studies, the Korea missionaries from North America even wanted Korean Christianity to be 'a Biblical Christianity' (Rhodes 1934).

The place of the Bible in all the work of the Missions has been made very prominent. To this emphasis also the Koreans responded. They have always venerated the scholar and books ... In 1906, the Mission passed a resolution of appreciation of the work of the Bible societies as follows: 'The Christianity that is being developed in this land is pre-eminently a Biblical Christianity ... It is the Bible that is the daily food of the Korean Christian, his spiritual meat and drink. The Bible holds the chief place in the mental and spiritual nourishment of a multitude of people in this land'. (p. 253)

Here it is helpful to see how the NM's Biblicist Bible study classes worked and paid for Korean Protestants. Firstly, for a traditional Korean Christian taking the Bible classes in spite of many sociopolitical, cultural and religious difficulties was a kind of initiation ceremony to be a real Christian. For traditional Koreans, accepting Christianity meant being alienated not only from their traditional religions, but from their family and community ties. In order to compensate for their feeling of alienation, they tended to complete the rather strict initiation ceremony, which, nevertheless, turned out to be something sweet, providing them with what they had ardently wanted: opportunities of learning and becoming someone.

Secondly, those Korean Christians, who had undergone the initiation ceremony, naturally came to have a strong commitment to their churches, which in turn drove them to bring their family members or neighbours to their churches. This explains how the 'self-propagation' as the first principle of NM worked, and how the Korean Protestant churches came to experience an unusual growth.

Thirdly, the strong commitment brought about not only a rapid church growth, but a strong giving by which the 'selfsupport' was possible. The No. 5 rule of NM prohibited native Korean ministers to get paid from a foreign fund, and because it was taken for granted that a local church had to do 'self-support', most of its members actually served it willingly for free. Furthermore, Korean Protestants were eager to congregate for not only various worship services - Sunday morning and night, midweek (Wednesday) night, and daily daybreak - but for construction of church buildings, alms giving and evangelism. So, with fervent willingness to congregate, to give and to help their church with many kinds of labours and offerings, Korean Protestants were well able to establish their church buildings, and do various kinds of educational and charitable works (Brown 1921):

Nowhere, in the world is there a higher percentage of church members who pray, study the Bible, attend devotional services, give proportionately of their money, and manifest evangelistic zeal in spreading the gospel. (p. 540)

Fourthly, enduring quite long systematic Bible study classes, Korean Protestants in general and Korean Presbyterians in particular, naturally learned about 'self-government' together with the church leadership, which was fairly democratic, a revolutionary experience for traditional Koreans in general, and especially for the poor and underprivileged ones, including women and children who had been worn out by centuries-old classism, sexism, and ageism. In Korea, where Confucian literati had been ruling for centuries, no one was seriously respected save them. The poor and uneducated people, and women in general, who were not allowed to have official education, were the most despised: this situation caused them to get literacy through the Bible study classes. In the churches, however, they were surely welcomed not only to learn letters, which was impossible for them otherwise, but to do something for a greater end: educational and charitable activities. So in the process, they unsurprisingly learned about the church's democratic leadership, and furthermore could carry out their leadership in due time, becoming a leader (deacon, elder or pastor). This democratic process meant a lot for low-class people and women, simply because they seldom had a way to be a meaningful leader otherwise.

Then how did the 'systematic Bible study classes' in the NM occasion a strong Biblicism in Korean Protestant churches in general? Firstly, the Korea mission field's uniqueness is to be noted: traditional Koreans' reverence and hunger for literacy led a multitude of low-class Koreans, women, and children, to Protestant churches, where they could become literate through various kinds of Bible studies. Secondly, the Korea missionaries from Western countries took good advantage of this unique Korean situation: having had a Biblicist view of the Bible, they had well regarded Biblicist teachings of the Holy Scriptures as the crucial mission work. Dr S.A. Moffett (1914:94) stated:

I believe that nothing has had more to do with the spiritual attainment of the Korean Christian than the Bible study of the Sabbath Bible Classes and the systematic study and training of the Leadership of the Church through the System of Bible Training Classes which has been such a marked feature of the work in Korea. The tens of thousands of men and women who 
every year are brought into such study of God's Word are receiving the spiritual food for the nourishment of the Christian life, and are showing the spiritual results in the steadfastness of their faith and the development of strength of character ... (p. 94)

Furthermore, the missionaries were unavoidably lacking in speaking Korean as a foreign language, and had only few reference books except for the Korean Bible itself. This situation necessitated them to teach the contents of the Bible just as they were in it, that is, in a Biblicist manner. Thirdly, the rarity of the Bible and the literate in the modern Korea led Korean Christians to revere the Bible even more than usual, reinforcing their Biblicism. The translation of the Bible into Korean was completed in 1911. Therefore, during the first decades of the Protestant mission in Korea (since 1884), Korean Protestants were using only the New Testament (translated into Korean in 1900) or a small booklet usually containing only the Gospel of Mark, of which the tractate form had been widely distributed for evangelism purposes. This situation tells us that it was not so easy for a Korean to buy a Bible even up to the 1920s, boosting reverence for the Bible. It is clear, therefore, that those conditions drove Korean Protestants to keep a firm Biblicism. Having a Biblicist 'contemporaneous hermeneutic' derived from centuries-old Neo-Confucianism, they had been fully ready to accept the Western missionaries' Biblicist teachings of the Bible, even accepting them as historical facts. So both the majority of the missionaries and their Korean followers could make a kind of synergy effect, developing a resilient Biblicism.

Here it is remarkable that the Biblicist learning of the Bible for the Korean Protestants had a good effect for them: having accepted the Biblical teaching as literally true, they tried to put it into practice. In other words, they did not accept the Bible teachings merely for literal or intellectual purposes, but as something to practice in their everyday lives. This was also a Neo-Confucian influence: Neo-Confucian literati learned their Confucian bibles to practice in their normal lives. For the part of the Korean Protestants, they wanted to be sure of their being different from other non-Christian Koreans, by doing something practically Christian: attending the church and its Bible study classes regularly, doing its other activities fervently, giving generously and spreading the Gospel to their neighbours. This explains why those Christian leaders who had been converted from Neo-Confucianism emphasised a robust spiritual endeavour (cf. Hwang 2007:101-119). It is no coincidence that the most popular book except for the Bible for early Korean Christians was John Bunyan's Pilgrim's Progress in its Chinese or Korean translation.

Prominent among the early Korean Protestants' practical doings was their durable evangelist practice, which was vital for Korean Protestant churches: it boosted not only Biblicist systematic Bible study classes, but church membership, achieving unheard-of church growth. Because Biblicism was believed to have entailed the remarkable church growth, it was in no doubt taken for granted as an undisputable truth. Additionally, it soon came to be sanctioned by PCK's creed in its first historical constitution adopted in 1907, the Biblicism becoming a standard article of faith or a touchstone for Korean Presbyterians. This situation, however, drove them to be intolerant to any other interpretation of the Bible than the Biblicist, developing their Biblicism into a fundamentalist dogma.

\section{The constitutional Biblicist creed of the Presbyterian church of Korea}

As we have seen, the three Biblicist elements had well worked together, eventually forming a firm Biblicism especially in PCK. Then, there was the fourth and last element, that is, the constitutional Biblicist creed of PCK, which made the Biblicism a binding law for Korean Presbyterians. The Biblicist creed was the first article of the so-called Twelve Articles of Faith, which was adopted in 1907 by PCK into its first historical constitution. PCK originally started with four Western Presbyterian mission bodies: American North and South, Canadian, and Australian. Having grown promptly, the four bodies became united to form PCK in 1907, adopting its constitution including both a creed (Twelve Articles of Faith) and a statement of Presbyterian polity. The Twelve Articles of Faith, originally known as the Creed of PCK or just the Presbyterian Creed, were written in India in 1904 by the India Presbyterian and Reformed missionaries from Western countries, and became the uniting creed of various Presbyterian and Reformed churches in North India in 1905. So when the four Western Presbyterian mission bodies in Korea were united, they also adopted the Twelve Articles of Faith (Hwang 2011:200-210). This creed, which was a summary form of the Westminster Shorter Catechism, had a mild Calvinism adjusted into a foreign mission field, yet its first article was outstanding, with a characteristic emphasis on the Bible as the Word of God (Hwang 2011):

Article I. The Scriptures of the Old and New Testaments are the Word of God, the only infallible rule of faith and duty. (p. 204)

Here the article clearly states: what is 'infallible' is not directly the Bible, but the 'rule of faith and duty', as it is taught in the Bible. But unfortunately the majority of the Korean Presbyterians took the word 'infallible' to mean the infallibility of the Bible itself. Furthermore, the term 'infallible' in the original constitution of 1907 was translated into hwaksilhan meaning certain, but later in 1932 changed into cheonghwak muohan meaning exact and inerrant: so the creed was believed to hold the doctrine of the Biblical inerrancy. Beginning from the late 1920s, there seemed to be some Presbyterian pastors, who had challenged the Biblicism, while trying to introduce various interpretations of the Bible on the basis of the Western sources. So in 1932 the leaders of the PCK even strengthened its position on the Biblicism, which now became a touchstone for Korean Presbyterians.

Then in the 1930s the strict Biblicism of PCK, which had been even sanctioned by its constitution, came to bring about some famous Korean versions of the American modernistfundamentalist controversy. Although Korean Presbyterian pastors were subscribing to their constitutional Biblicist creed, 
they had already learned about a lot of hermeneutic problems of the Bible, and also got to know that quite a lot of the Bible verses could not be literally understood or followed in their Korean situations. In 1934 there arose a famous modernistfundamentalist controversy. A Presbyterian pastor suggested that women could also be ordained elders (then it was even unthinkable because of strong anti-feminist elements of Confucianism), challenging the Biblicist interpretation of 1 Corinthians 14:34 ('Let your women keep in silence in the churches'). Then the next year saw another controversy: a Presbyterian pastor said that The Book of Genesis included part of the Ancient Hebrew legends, meaning that all of it was not directly the Word of God. Both pastors, however, were disciplined: they were judged to have violated the first article of the Twelve Articles of Faith in the Constitution of PCK. These incidents now openly and clearly showed that the Biblicism was the Church's official position, which every Presbyterian had to follow. Yet the Biblicism was so seriously challenged by the somewhat liberal wing of PCK in the post-liberation period that the Church fatefully was divided into four subdenominations: two conservative and two relatively liberal.

\section{The practical and fundamentalist aspects of the Korean Biblicism: The cases of Revs. Samuel Moffett and William Reynolds}

\section{Rev. Samuel Moffett's practical Biblicism}

As we have seen, the Korean Biblicism had been so distinctive that it had had a significant influence on Western missionaries in Korea and Korean theologians. Here we will describe the two distinctive theological aspects of the Korean Biblicism, the one being practical represented by Rev. Dr Samuel A. Moffett, and the other being fundamentalist characterised by Rev. Dr William Reynolds.

Rev. Dr Samuel Austin Moffett (Mapo Samyul in Korean, 1864-1939), who was a pioneering American Presbyterian (North) missionary (1890-1934) in Northern Korea, and the founder and dean of the Presbyterian Seminary in Pyongyang (1901-1922), held a strong Biblicism on practical grounds. While working in the poverty-ridden Pyongyang area in those critical years, he eye-witnessed the practical value of Koreans' vigorous Biblicist reading of the Bible, as it was practiced in the systematic Bible study classes in the NM. Rev. Moffett, therefore, stressed spiritual benefits of the Biblicist reading of the Bible, seldom expressly teaching something like the doctrine of the Biblical inerrancy. He saw two obvious 'spiritual' benefits that the Biblicism could give to Koreans.

Firstly, he believed that the Biblicist learning of the Bible brought about certainty of being saved, especially the Holy Spirit with the Word of God cleansing the believer's heart, as he said (1913):

It is crucially important to study the Word of God. The Word becomes the food protecting our spirits, and the Holy Spirit with the Word cleanses our hearts. Therefore, the believers in Jesus Christ shall read some Bible verses in their daily pre-appointed times with their family members. They shall also read the Bible in their leisure times, and especially on Sundays, they shall carefully meditate on the verses that they have been reading. While reading the Bible, they shall not simply read the words in it, but obey their meanings. (p. 14)

Here it is clear that Rev. Moffett was aware of the interpretive problems of the Bible: this explains why he says: not the Word alone, but 'the Holy Spirit with the Word cleanses our hearts'. He also said (1914):

in all Evangelistic work, both Missionary and Korean Christian, lay the emphasis on the great underlying spiritual truths of God's Word, believing that the Gospel is the power of God unto salvation, that regeneration is the work of the Spirit of God through the Word of God. (p. 93)

What was important was not merely the literal value of the Word, but 'the Holy Spirit with the Word', a good way to avoid the fundamentalist thrust inherent in the Biblicism. What makes his Biblicism more special is that he so emphasised the preaching of the Word of God that he even depreciated the Western civilisation and education, whose transmission to Koreans was almost identical with the preaching of the Word of God for other Western missionaries. So declares Rev. Moffett (1906):

Reformation is not redemption. Salvation from sin, not mere moral reformation, is the essence of the Gospel message. Civilisation is not Christianity. Western ideas, customs and inventions are not an essential part of Christianity. In fact many Oriental ideas and customs conform more nearly to the scriptural ideas than do some of the peculiar notions and customs of the Western world and the introduction of much that is considered a part of Western civilisation is a hindrance rather than a help to spiritual life. Our commission is to introduce spiritual Christianity, not Western civilisation. Education is not regeneration. We are not called upon in the evangelisation of Korea to provide a secular education for the heathen, but are commissioned to preach the Gospel to the heathen and to establish the Church of Jesus Christ. (p. 239)

Secondly, Rev. Moffett deeply experienced the practical value of Koreans' Biblicism, which, he believed, drove them to establish and make their churches grow. 'Dr Moffett's singlehearted desire was bringing people to Christ and to plant churches for them' (Shearer 1965:468). He firmly believed that the best way to make his desire come true was the systematic Bible study classes as they were done in the NM. He even changed NM slightly, putting emphasis on the systematic Bible studies, as his version of NM tells (Blair 1934:6):

1. It is the duty of every Christian to do the work of evangelism.

2. The Bible is the inspired Word of God so that systematic Bible instruction for the whole Church is indispensable.

3. The Korea church should be self-supporting from the beginning.

4. The church should be self-governing at the earliest possible time.

Moffett's version of NM is almost the same as NM, yet it is plain that he regarded 'the systematic Bible instruction' as the most vital element in NM. Above all, in contrast to the original 
NM, he added No. 2, emphasising that 'the Bible is the inspired Word of God'. The main reason is surely that the systematic Bible instruction is the basis of not only 'the work of evangelism' (No. 1), but of both 'self-supporting' (No. 3) and 'selfgoverning' (No. 4). It is clear that Rev. Moffett firmly believed not only that the Bible was inspired by God, but that the Bible itself had 'the self-evidencing power'. Therefore, the preacher must believe that when he preaches, he delivers the Word of God, a strong Biblicist character (Moffett 1906).

Emphasis should be placed upon the fact that your message is not yours but the message of the living God, whose existence and the inspiration of whose wordare facts to be proclaimed, not propositions to be proved. Rest your authority upon the Scriptures, the authoritative Word of God, which claims man's obedience. Get men to read it - read it to them and make it known as God's message which speaks for itself and needs no apology. Dr Chalmers says: 'We firmly believe that there is no one position of theology which can be more strongly and more philosophically sustained than the self-evidencing power of the Bible.' (p. 243)

Rev. Moffett so emphasised the Bible as the Word of God, strongly believing that it in itself has the 'self-evidencing power'. Here it is clear that he seldom used a Biblicist doctrine of the Biblical inerrancy, just emphasising the usefulness of the simplistic, Biblicist studies of the Bible. So it may be safe to say that Rev. Moffett did not develop a doctrine of the inspiration or inerrancy of the Bible, even if he is believed to mention it in some places. It was rather Rev. William Reynolds, who developed and taught the doctrine from the 1930s.

\section{Rev. Dr William Reynolds' fundamentalist Biblicism}

Rev. Dr William D. Reynolds or Lee, Nulseo in Korean (1867-1951; Professor of Systematic Theology at the Presbyterian Seminary in Pyongyang: 1905-1934) also witnessed how the Biblicism worked for the Korean Protestant churches' unusual growth, but, as a theologian, tried to make an elaborate doctrine of the inspiration and inerrancy of the Bible, which apparently had a fundamentalist inclination. He was arguably the most influential theologian in establishing a firm Biblicist theology which eventually became the doctrinal basis of the Korean Protestant churches in general and of PCK in particular. He taught the Biblicist, Old Princeton theology to most of Korean Presbyterian pastors for the formative 30 years of PCK (1901-1930), influencing them to have a very conservative and even fundamentalist theology. We will examine the three decades in which he developed his Biblicist Old Princeton theology into a fundamentalist theology.

Firstly, in the 1910s, he presented a simple doctrine of the Bible as the Word of God. In a booklet on an introductory theology (Lee 1916), Dr Reynolds listed about 200 'evidences for the Old and New Testaments to be the Word of God', not presenting the doctrine of the inspiration and inerrancy of the Bible. It is obvious that he did not yet need to present the doctrine, perhaps because there did not arise any significant question regarding the authority of the Bible up to that period.
Secondly, in the1920s, Dr Reynolds carefully taught the doctrine of the inspiration of the Holy Scriptures. Here we can see a kind of transition for him to move from a simple doctrine of the Bible as the Word of God to an advanced doctrine of the inspiration of the Bible. Here Dr Reynolds (Lee 1920:77-78) introduced the Biblicist doctrine of Dr Charles F. Wishart of McCormick Theological Seminary, Chicago, USA, who insisted on the doctrine of the 'verbal and plenary inspiration' of the Bible. But in this period, Dr Reynolds still seemed to be very cautious to present the doctrine, maybe because the Korean situation, which took the Biblicism still for granted, did not yet strongly necessitate him to do so.

Thirdly, in the 1930s, Dr Reynolds turned to be very defensive for the authority of the Bible, surely because there arose some weighty questions about it, as we have seen above. So, dealing with those questions, he became combative toward the modernist and liberalist wing, eventually developing a strong doctrine of the 'verbal and plenary inspiration' of the Bible, which naturally had a fundamentalist implication. This judgment may be justified when we see him to have militantly attacked a theological modernist as a 'traitor of Christianity' or an 'anti-Christ' (Lee 1932:6-11). Another important evidence for him to be classified as a fundamentalist is that he even denied the theory of evolution (Lee 1934:47-50).

Dr Reynolds' Biblicism surely has a fundamentalist tendency, but it has also an overall healthy Biblicism, which did not only include Rev. Dr Moffett's practical Biblicism, but Confucian reverences which could well appeal to Korean Christians. A chance passage from Reynolds' dogmatics (Ga 1931) ${ }^{5}$ reveals this stance:

Formerly Confucius spoke, 'it is just one word that can make a nation prosper or perish.' This tells us how important even a word can be. The words in the Bible, moreover, matter for people's eternal life or death. Then, if even a word in the Bible is wrong, its consequences are not to be small. Therefore, it is to be taken for granted that for the matters of the Biblical revelations, not only the meanings of the words in the Bible, but the words themselves were also inspired [by the Holy Spirit] ... We sincerely believe and do not doubt that the Holy Scriptures never has anything inerrant, because the words in them were originated from the revelations of the Holy Spirit ... But the modernists, who do not believe in the power of the words, say that 'the authors of the Bible could be inerrant.' Then we ask, if there were an inerrancy, when did it take place? How can we distinguish when there was a revelation and when was not? How can we defend the Bible, if a part of it is revelation, while another part of it is not revelation? (pp. 68-70)

Dr Reynolds got to know from a Confucian tradition that the Bible was absolutely authoritative word by word, and he even reinforced his Biblicism to the extent that he articulated a fundamentalist theology. Yet it is clear that his Biblicism still included a healthy Biblicism, which was derived from that of Rev. Samuel Moffett. This means that Dr Reynolds'

5.Ga, Okmyeong (Chia, Yuming) (1931), Gidokkyo Jeungheomron (Evidences of Christianity), (Chia, You first systey), Changnon the first systematic theology printed in Korean, was Written by Yuming Chia, a Chinese theologian, and edited and translated into Korean by some Korean pastors under the supervision of Rev. William Reynolds, who used it as a theological text book at the Pyongyang Presbyterian Theological Seminary. 
Biblicism may be useful, only if it is devoid of its characteristic fundamentalist tendency.

\section{Conclusion}

We have studied the origin and early stages of the Biblicism of the Korean Protestant churches in general and PCK in particular, seeing that it made a significant influence not only on their unusual growth, but on their Fundamentalism and many schisms in the post-liberation era. The Biblicism of the Korean Protestant churches naturally had two original elements: the Old Princeton doctrine of the Biblical inerrancy from the North American missionaries in Korea and the centuries-old NeoConfucian biblicism from Korean Protestants. The one was well integrated into the other, producing a firm Biblicism, which became even firmer, when it was institutionalised by the Nevius (mission) Methods, and sanctioned by the first and historical constitutional creed of PCK.

The Korean Biblicism was developed into two more or less different theological forms: the one being practical and the other dogmatic and fundamentalist. The first was unfolded by Rev. Samuel A. Moffett, who emphasized the practical meanings that Biblicist Bible study classes involved (helpful for church-planting and growth). On the other hand, Rev. Dr W.D. Reynolds developed the Biblicism into a fundamentalist doctrine, defending and attacking it against not only theological modernism, but also the theory of evolution.

The Korean Biblicism, especially in its early decades surely worked great, giving priority to systematic Bible study classes, which every new Korean Protestant was to take. This course was wholeheartedly welcomed by Korean Protestants in general and Korean Presbyterians in particular, providing them with not only opportunities of learning (not merely literacy, but Western things), but possibilities to become leaders (deacon, elder and pastor). This explains how the Korean Protestant churches, especially in their early period, made a spectacular growth. This growth, however, has justified the Biblicism, taking it for granted, and making it an absolute doctrine. Hence it has in the course given rise to a fundamentalism.

As we have seen in the cases of the early Korean Protestants, a Biblicism is based usually on traditional Koreans' simple reverence for a bible. This kind of simple reverence, which often lacks knowledge of complexities and differences of things, can fairly easily be exploited for a fundamentalist or factionist cause. This gives us a good practical implication. If a Biblicism may remain a simple reverence for the Bible, it will be a good stimulus for church growth. But if it would be developed as a fundamentalist doctrine, it could effortlessly be a schismatic weapon against a liberal or modernist wing.

\section{Acknowledgements}

I would like to express my deep gratitude to Mr Todd Tilton, who has encouraged me not only with proofreading, but with deep love for Korean churches. I also give thanks to
Professor James Bryan Pattison, who has encouraged me with high appreciation for the present article.

\section{Competing interests}

The author declares that he has no financial or personal relationships which may have inappropriately influenced him in writing this article.

\section{References}

Bartkowski, J., 1996, 'Beyond Biblical literalism and inerrancy: Conservative Protestants and the hermeneutic interpretation of scripture', Sociology of Religion 57(3), 259-272. http://dx.doi.org/10.2307/3712156

Blair, W.N., 1934, 'Samuel A. Moffett: On his seventieth birthday', The Presbyterian pp. 4-9.

Brown, A.J., 1921, The mastery of the far east: The story of Korea's transformation and Japan's rise to supremacy in the Orient, Charles Scribner's Sons, New York.

Choi, Y.Y., 2008, 'Seodangeu Gyoyug Bangbeobgwa Hyeondaejeog Eueu' [The educational methods and contemporary significance of Seodang] Hanmungojeonyeongu [Studies of Chinese Classics] 17, 341-366.

Chun, T., 1964, 'Hankuk Gyohoe eu Jidojasang' [A sketch of Korean churches' leaders], Kidokgyo Sasang [Christian Thought] 8(7), 43-45

Clark, C.A., 1930, The Korean church and the Nevius methods, Fleming H. Revell Co., New York.

Ga, O. (Chia, Yuming), 1931, Gidokkyo Jeungheomron [Evidences of Christianity], Changnoheo Sinhakkyo, Pyongyang, Korea.

Gale, J.S., 1898, Korean sketches, Fleming H. Revell Co., New York.

Gale, J.S., Apr., 1914, 'Bible institutes', Korea Mission Field 10(4), 115-116.

Gale, J.S., Jan., 1914, 'Korea's preparation for the Bible', Korea Mission Field 10(1), 4-6.

Hodge, A.A., 1860, Outlines of theology, Robert Carter \& Brothers, New York.

Hodge, C., 1883, Systematic theology, vol. I, Charles Scribner's Sons, New York.

Hwang, J.-B., 2007, 'Rev. Kil Son-Ju's theology emphasising spiritual endeavor, revivalism and Biblical inerrancy', Acta Koreana 10(2), 101-119.

Hwang, J.-B., 2011, 'The first Asian ecumenical confession of faith: The so-called twelve articles of faith of many Asian Protestant churches', The Ecumenical Review 63(2), 200-210.

Kalton, M., 1988, To become a sage: The ten diagrams on sage learning (Neo-Confucian studies), Columbia University Press, New York.

Kil, S.-j., 1935, 'Malsehak' [Eschatology], Sinangsaenghwal [Life of faith] 4(7), 14-16.

Kil, C.-g., 1980, Yŏnggye Kil Sŏnju [A biography of Kil Sŏn-ju], Chongno sŏjŏk, Seoul, Korea.

Kim, I. S., 2001, 'Nevius methods', in S.W. Sunquist (ed.), A dictionary of Asian Christianity, pp. 598-599, Eerdmans, Grand Rapids, MI.

Kim, L.-S., 1936, 'Yŏnggye Sŏnsaeng sojŏn' [A brief biography of Kil Sŏn-ju], Sinangsaenghwal [Life of faith] 5(1), 28-31.

Lee, N. (William Reynolds), 1916, Sinhakgonggwa [A common instruction in theology], Chosun Yasogyoseohoe, Pyongyang, Korea.

Lee, N. (William Reynolds), 1920, 'Sinhak Pyeonjeungron' [An apology for theology], Sinhakjinam [Theological Compass] 3(1), 77-78.

Lee, N. (William Reynolds), 1932, 'Geundae Sinhakjueui-neun Baedohaneun II' [Theological modernism as a betrayal of Christianity], Sinhakjinam [Theological Compass] 14(6), 6-11.

Lee, N. (William Reynolds), 1934, 'Jinhwaron-eul Buinhaneun Jesasil' [Many facts that deny the theory of evolution], Sinhakjinam [Theological Compass] 16(5), 47-50.

Makeham, J., 2003, Transmitters and creators: Chinese commentators and commentaries on the Analects, Harvard University Press, Cambridge, London.

Meeter, J.E. (ed.), 1973, Selected shorter writings of B. B. Warfield, vol. II, Presbyterian and Reformed, Phillipsburg, NJ.

Moffett, S.A., 1906, 'Policy and methods for the evangelisation of Korea', Chinese Record 37, 235-248.

Moffett, S.A., 1914, 'Individual life of the Korean Christian', Korea Mission Field 10(4), 93-95.

Rhodes, H.A. (ed.), 1934, History of the Korea mission, Presbyterian church, U. S. A., vol. I, 1884-1934, Y. M. C. A. Press, Seoul, Korea.

Rogers, J.B. \& McKim, D.K., 1979, The authority and interpretation of the Bible: An historical approach, Harper and Row, Publishers, San Francisco, CA.

Ryu, D.Y., 2008, 'The origin and characteristics of evangelical Protestantism in Korea at the turn of the twentieth century', Church History 77(2), 371-398. http://dx.doi. org/10.1017/S0009640708000589

Shearer, R.E., 1965, 'The evangelistic missionary's role in Church growth in Korea', The International Review of Missions 54, 462-470. http://dx.doi.org/10.1111/j.17586631.1965.tb01896.x

Student Volunteer Movement for Foreign Missions, 1909, Students and the present missionary crisis: Addresses delivered before the sixth international convention of the student volunteer movement for foreign missions, Student Voluntee Movement for Foreign Missions, Rochester, NY.

Zhu Xi, 1983, Sishu Zhangju jizhu [Section and sentence commentaries and collected annotations on the four books], Zhonghua Shuju, Beijing, China. 